\title{
STUDENTS' ATTITUDE TOWARDS MATHEMATICS: DOES CLASSROOM LEARNING ENVIRONMENT OF SINGLE- GENDER CLASSES MAKE ANY DIFFERENCE?
}

\author{
Muhammad Afzal* \\ Khalid Saleem $^{* *}$ \\ Mobeen ul Islam ${ }^{* * *}$
}

\begin{abstract}
Mathematics is an important subject as it supports most of the social sciences and almost all natural sciences. Both the teaching and teaching and learning aspects of Mathematics are quite different from other subjects of the social sciences as well as the natural sciences. Therefore, teaching and learning process of Mathematics demands specific learning environment and Mathematics related attitudes both of the teachers and the students. Studying these aspects in single-gender classroom becomes even more significant. The study at hand focuses on exploring the relationship between these two variables on the basis of gender. The 11th grade male and female Mathematics students enrolled during academic year 2012-2013 in public sector colleges of Punjab province of Pakistan constituted the population of the study. The sample of the study included randomly selected 1717 students from the public sector colleges located in six randomly selected districts of the Punjab province. In order to collect data, two Urdu translated questionnaires namely, What Is Happening in This Class (WIHIC), and Questionnaire of Mathematics-Related Attitude (QOMRA) were used. The data was collected in the last month of the academic year so that the attitude of students in real sense may be determined. Research findings revealed that male and female students'
\end{abstract}

\footnotetext{
* PhD Education Scholar, University of Management and Technology, Lahore, Pakistan

${ }_{* * *}^{* *}$ Director, University of Education Lahore, Okara Campus, Pakistan

*** Assistant Professor, University of Gujrat, Gujrat, Pakistan
} 
perception about their classroom learning environment significantly differs from each other. The male students perceived more supportive learning environment in Mathematics classroom than the female learners. Moreover, it was also found out that classroom learning environment has a feeble effect on students' attitude towards Mathematics. However, it was found that the male students showed relatively more positive attitude towards Mathematics than the female students.

Keywords: Classroom learning environment, attitude towards Mathematics, single-gender classroom.

\section{Introduction}

Single-gender classrooms are preferred in most of the indigenous as well as religious societies like Pakistan. But in the recent years, it has been preferred over the Co-education system even in the advanced countries like United States of America (Novotney, 2011). Major differences, such as religious prohibition, cultural traditions, and social setup requirements are taken as evidence for the single-gender education.

Teaching of Mathematics in single-gender classroom requires certain types of specific roles and responsibilities of the teachers resulting in a particular learning environment. Such learning environment may shape attitudes which can differ from that of Co-ed situation. The present study aims at determining the relationship of single-gender classroom learning environment with the students' attitude towards Mathematics.

The quality of education depends not only upon the subjects taught and the level of achievement, but also on the learning environment of the particular class. Behavior of students may be reflected or influenced by the environment within or outside the school (Condition of Education, 1998). The notion of classroom learning environment is being studied since the 1930s (Vacha, 1977; Goh \& Fraser, 1998; Maat \& Zakaria, 2010). Previous researches have revealed that the quality of classrooms' environment has significantly influenced the students' learning (Fraser, 1994, 1998). 
Classroom is a place where students and teachers interact with one another and use different instructional tools, information and sources for learning activities (Wilson, 1996). Like many other aspects of social sciences, it is difficult to define the term 'learning environment' precisely and accurately because it may vary according to prevailing contexts, demographic situation and social norms. Learning environment usually consists of some observable characteristics such as school buildings, instructional tools, learning attitude of the students, teaching aptitude of the teachers and interactions among the learners and instructors (Brophy, 1999; Fraser \& Walberg, 1991; Moos, 1979). Dorman (2002) defines it as "atmosphere, ambience, tone, or climate" whereas, Henderson, Fisher, and Fraser (2000) confine it to only one aspect i.e. psycho-social classroom learning environment. Similarly, Galbraith $(1989,1990)$ describes two types of classroom environment; physical environment and the psycho-social classroom environment. Both components significantly influence the learning outcomes of students (Rawnsley \& Fisher, 1998).

Mathematics has acquired the status of a compulsory subject up to a certain academic levels in almost every nation of the word. The need of people for reckoning in everyday life has caused a change in their attitude towards Mathematics. In the Pakistani perspective no research study is available which may describe how male and female students differ in their attitude towards Mathematics. The study in hand is an effort to determine whether there exists any difference in the male and female students' attitude towards Mathematics. In the same way the study also explored the nature of Mathematics classroom environment persisting in Pakistani secondary schools for boys and girls. Finally gender based comparison of the effect of classroom learning environment on the students' Mathematics related attitude was also made. The objectives of the study were as under:

1. To investigate Mathematics classroom learning environment in a single-gender class.

2. To assess the students' attitude towards Mathematics.

3. To explore the relationship between Mathematics classroom learning environment and single-gender students' attitude towards Mathematics. 
To judge the level of achievement of the above stated objectives following hypotheses were tested;

1. There is no significant difference in male and female students' perceptions about classroom learning environment

2. There is no significant difference in male and female students' perceptions about their attitude towards Mathematics.

3. There is no significant relationship between classroom learning environment and students' attitude towards Mathematics.

\section{Theoretical Background}

The study at hand is based on the assumption that learning environment affects students' attitude towards Mathematics in one way or the other. So, an attempt has been made to explore the relationship of Mathematics class learning environment and the Mathematics related students' attitude at college level in Pakistani perspective.

\section{Mathematics Classroom Environment}

In the present study, two aspects i.e. learning environment of Mathematics class and students' Mathematics related attitude were explored. Gender is a demographic component which was also examined in relation to these aspects. Classroom learning environment refers to the prevailing circumstances of a particular classroom. It is observed that students perform better when their perception about classroom environment is positive.

Herbert (1978) describes that mathematics as the Queen and Servant of all the science subjects. It supports the learning of science subjects like Physics, Chemistry, Biology and Economics. Teaching of Mathematics and Mathematics classroom learning environment hold valuable concern in the present era. Maat and Zakaria (2010) investigated the links between learning environment and attitude towards Mathematics. Significant associations were found as students with a positive perception about environment of classroom and having more optimistic views about their teachers are more interested to learn Mathematics. Similarly, Reynolds and Walberg (1992) conclude that student' positive perceptions about environment of their classroom significantly contribute in developing a positive attitude towards Mathematics. 
Classroom learning environment is not a single entity but a combination of different aspects. Some important aspects like teacher support, student cohesiveness, involvement, co-operation, task orientation, and equity may help in developing positive classroom learning environment (Fraser, 2002a).

\section{Gender Differences and Mathematics Classroom Environment}

Needs and interests of females and males differ significantly in almost all the spheres of life. The same is the case with the perceptions of male and female students about learning environment of the classroom. Researches in the past had also supported the fact. According to Goh and Fraser (1998) females perceive more favorable classroom environments than males although Mathematics achievement favors the males.

Students' cohesiveness is the degree of students' familiarity, sociality and cooperation with one another. Vacha (1977) insists that in cohesive classrooms students value their peers, try to help and care about each other. In addition, Moos (1974) conclude that Mathematics achievement and class cohesion is highly associated at school level. Similarly, Anderson and Walberg (1974) found that cohesiveness is positively associated with student learning. Moreover, Lawrenz (1987) reported that the girls exhibit more cohesiveness in their classes than boys.

Teacher support is an important feature of classroom environment. It is the degree to help, trust and interest of the teachers for the students. Rawnsley and Fisher (1998) conclude that the students show positive attitude towards Mathematics when their teacher is supportive and cooperative. Similarly, Akey (2006) concludes that the success of the students depends upon the supportive teachers who build up feelings of control and confidence among their students to learn in the class properly. The teacher's disposition affects the students' perception to modify their attitude. Moreover, male students perceive that their teachers are more supportive and they show more involvement in Mathematics classroom as compared to the female students (Mobeen-ulIslam, 2012). Furthermore, Fisher and Rickards (1998) reported that students are more inclined towards Mathematics when their teachers reflect leadership and friendly behaviors in their classrooms. On the other hand, they show more negative attitude when they perceive their teachers as admonishing and imposing strict behaviors. Additionally, 
Kim, Fraser, and Fisher (2000) observed that boys perceived their teachers to be more supportive as compared to girls.

Involvement is the major component of classroom environment. It is the degree of participation of the students in discussions for enhancing their work capacity and enjoyment. Huang and Waxman (1995b) contend that females show more favorable perceptions than males. Moreover, in single-sex classrooms female show more involvement, attentiveness, affiliation with their peers, and enjoy their Mathematics class more than males. While on the other hand, Kim, Fraser, and Fisher (2000) found that male show more Involvement in classroom activities than females. Similarly, Khoo and Fraser (1998) reported that the males perceived greater involvement than females. Similarly, Task Orientation is another aspect of classroom environment. It is the degree to complete planned activities by sticking to the subject matter. Mobeen-ul-Islam (2012) claims that the task oriented classroom learning environment is positively correlated with students' attitude towards mathematics. In another study Kim, Fraser, and Fisher (2000) affirm that the boys perceived their classrooms more Task Oriented than girls.

Co-operation also plays vital role in classroom environment. It is the degree of students' support to one another to complete the learning tasks. According to Mobeen-ul-Islam (2012) cooperative and equity based classroom learning environment is positively correlated with students' attitude towards Mathematics. This shows that students' achievements in Mathematics may be enhanced by cooperation and equity. Similarly, Bono (1991) reported that girls show more enjoyment and positive attitude towards mathematics if they were taught in a cooperative setting. Moreover, female show more cohesiveness and cooperation in classroom than males (Rawnsley \& Fisher, 1997). In another study, Baker and Jacobs (1999) indicate that girls feel more supportive to each other, more enthusiastic to participate in the single-sex classroom and show less selfconscious attitude without the boys.

Like other aspect of classroom environment, equity is also an important factor. It is the degree to which the teacher treats the students equally. According to Kim, Fraser, and Fisher (2000) boys perceived more equity than girls in their classrooms. Contrary to this, girls perceived more equity than boys (Khoo \& Fraser, 1998; Koul \& Fisher, 2004). 


\section{Students’ Attitude towards Mathematics}

Different aspects of attitude are defined by different researchers. Ramsden (1998) states that the researchers use the words like attitude, interest and motivation for different emotional states of human mind. Salta and Tzougraki (2004) defined an attitude as the inspirational power to think, feel, and act or react positively or negatively towards various objects existing in environment. Similarly, students' attitude towards a certain subject can motivate them to perform and behave well in the classroom. There are different factors that affect the students' attitude towards Mathematics. Some of these factor are parental and teacher support, societal factors, and the students' stimulus in general. In the same way, attitude is also described as the positive or negative degree of effect which is related to a specific subject. It means that students' Mathematics related attitude is positive or negative emotional disposition (Haladyna, Shaughnessy \& Shaughnessy, 1983; McLeod, 1992).

Students' attitude towards Mathematics is not a single entity but a combination of different aspects, like attitude towards Mathematics inquiry, enjoyment of Mathematics lessons and adoption of Mathematics attitude. Attitude towards Mathematics inquiry evaluate one's preference towards using inquiry in Mathematics. Moreover, adoption of Mathematics attitude measures one's readiness to change opinion built on empirical data. Furthermore, enjoyment of Mathematics lessons judges one's level of enjoyment during study of classroom Mathematics lessons (Mobeen-ul-Islam, 2012).

\section{Gender Differences in Mathematics Related Attitude}

The gender differences in mathematics have been a topic of research over the past few decades. Mathematics achievement varies across regions, nations, and a variety of socio-economic and demographic features. Gender is one of the most pondered over aspects related to Mathematics learning (Halimah \& Noor, 2006).It is a matter of fact that males and females show same level of confidence in their Mathematics ability during school education while at higher level of education male students are more confident than the females in learning Mathematics (Pajares \& Graham, 1999).The recent researches indicate that these differences are even prevalent in some areas of complex Mathematical tasks (Mullis, et.al., 2001). 
Different studies point out that Mathematics has always been a male domain and there is strong evidence that girls show less confidence in Mathematical work as compared to the boys (Hyde, Fennema, Ryan, Frost, \& Hopp, 1990; Odell \& Schumacher, 1998; Meelissen \& Luyten, 2008). However, in many other researches, it has been shown that there is no significant gender based difference about attitude towards Mathematics (Mohd, Mahmood, \&Ismail, 2011; Köğce, et al., 2009; Nicolaidou \& Philippou, 2003). Gill (1994) also concludes that girls at elementary and secondary level show positive attitude towards schools but negative attitude towards Mathematics. In addition, Swetman (1995) describes that girls show more positive attitude towards Mathematics as compared to the boys during their early education but they lose their interest level in Mathematics as they grow older. He suggests that the teachers should facilitate the girls to develop a positive attitude towards Mathematics for their better performance in Mathematics.

It is generally believed that girls are relatively weaker in Mathematics than boys. Different studies have been carried out on the present topic in different cultures but, in Pakistani perspectives there are few such studies. In fact, parents and teachers may be responsible for low achievement of females in Mathematics. Many teachers, particularly females, actively motivate and encourage male students to continue in their Mathematics studies more than they encourage girls. Similarly, parents also feel that females show less interest in Mathematics. Females never come up to the standard level of competence in Mathematics because it requires extra devotion, determinations and intelligence.

\section{Relationship of Classroom Environment with Students' Attitude towards Mathematics}

Classroom environment, shaped by teacher-student and student-student relationships, has been widely studied because of its effects on students' outcomes (Church, Elliot, \& Gable, 2001; Wentzel, 1998; Ames, 1992). The meaningful classroom environment can meet basic psychological needs of children like autonomy, competence and relatedness for the achievement of the objectives (Brock, Nishida, Chiong, Grimm, \& Rimm-Kaufman, 2008). Moreover, Maat and Zakaria (2010) investigated relationship between learning environment and the students' attitude towards Mathematics. Similarly, Simpson and Oliver (1990) reported that the classroom environment strongly affects the students' attitude and 
achievement. Finally Reynolds and Walberg (1992) conclude that students' positive perceptions about the environment of classroom contribute in developing a positive attitude towards Mathematics.

According to Midgely, Feldlaufer, and Eccles (1989) the Mathematics classroom environment including the teacher's self-efficacy beliefs, significantly influence the students' motivation, confidence, and overall disposition towards Mathematics. Various researches (Fisher \& Khine, 2006; Fraser, 2007) show variations in perceptions of students about classroom environment based on their age and gender, teacher's gender and grade level etc. Huang (2003) investigated that females students show more positive attitude towards learning than boys. The results of the study reveal that outcomes regarding affective and cognitive aspects are affected by learning environment of the class.

\section{Methodology}

This study is descriptive in nature and to conduct this study, survey method was used. Following procedural steps were adopted to accomplish the goal.

Participants: The accessible population of the study comprised of $11^{\text {th }}$ grade Mathematics students enrolled in public sector male and female colleges during academic year 2012-2013 located in six randomly selected districts of Punjab province. In order to ensure adequateness and representation of the population, multistage sampling technique was used to draw the sample of $11^{\text {th }}$ grade 1717 (male (839 male and 878 female) Mathematics students. From each district eight colleges, including four boys and four women colleges, were randomly selected. From each of the selected college, two sections of grade 11 were again randomly selected.

Instruments: For data collection, two Urdu translated instruments namely, what is Happening in this Class (WIHICU) and the Questionnaire of Mathematics Related Attitude (QOMRA-U) were used. The first questionnaire (WIHICU) comprised of six factors namely student cohesiveness, teacher support, involvement, task orientation, cooperation and equity. There were 8 items in each factor of the questionnaire. Hence, there were total 48 items in the questionnaire. In the same way the second questionnaire (QOMRA-U) comprised of three 
factors namely attitude towards mathematics inquiry, adoption of mathematics attitude and enjoyment of mathematics lessons having seven items in the first factor and ten each in the last two. Finally, both the Questionnaires were translated in Urdu and validated by Mobeen-ulIslam (2012).The reliability coefficient i.e. Cronbach Alpha for the questionnaires was 0.805 and 0.798 respectively.

As far as the data collection is concerned, the researcher collected data personally and also with the help of research associates. The research associates were trained about carrying out the whole procedure of data collection. The respondents were given orientation by the researcher and research associates guided them about how to respond to different statements.

\section{Results}

The collected data was tabulated and analyzed using the software named Statistical Package for Social Sciences (Version 21). Findings drawn on the basis of data analysis are as under:

Table 1

Male and Female Students' Perception about Classroom Learning Environment

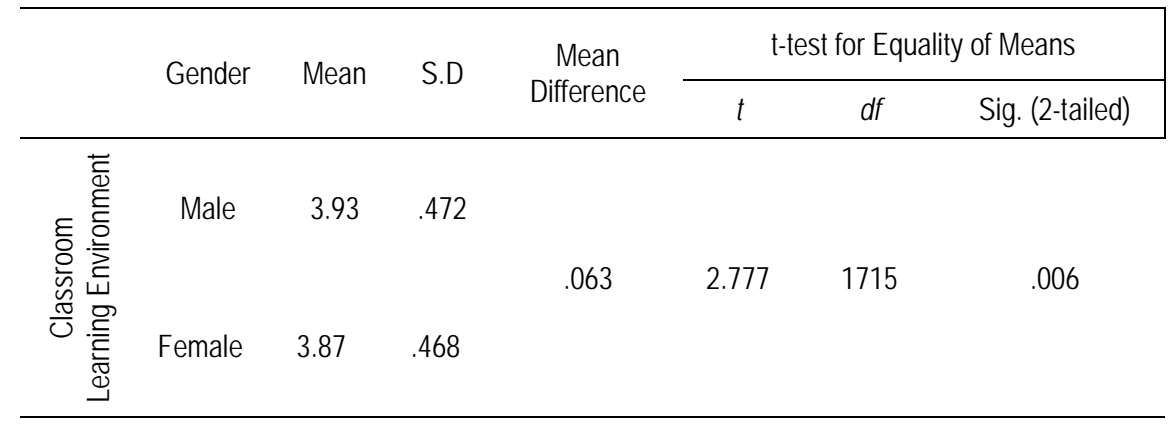

Analysis of data in the above table indicates that there exists significant difference $(\mathrm{p}=.006<.05)$ between male and female students' perception about classroom learning environment. Therefore, the null hypothesis "There is no significant difference between male and female students' perception about mathematics classroom learning environment" is rejected. The mean score for classroom learning environment of male students $(\overline{\mathrm{x}}=3.93)$ is more than that of females $(\overline{\mathrm{x}}=3.87)$. 
Table 2

Factor Wise Comparison of Classroom Learning Environment

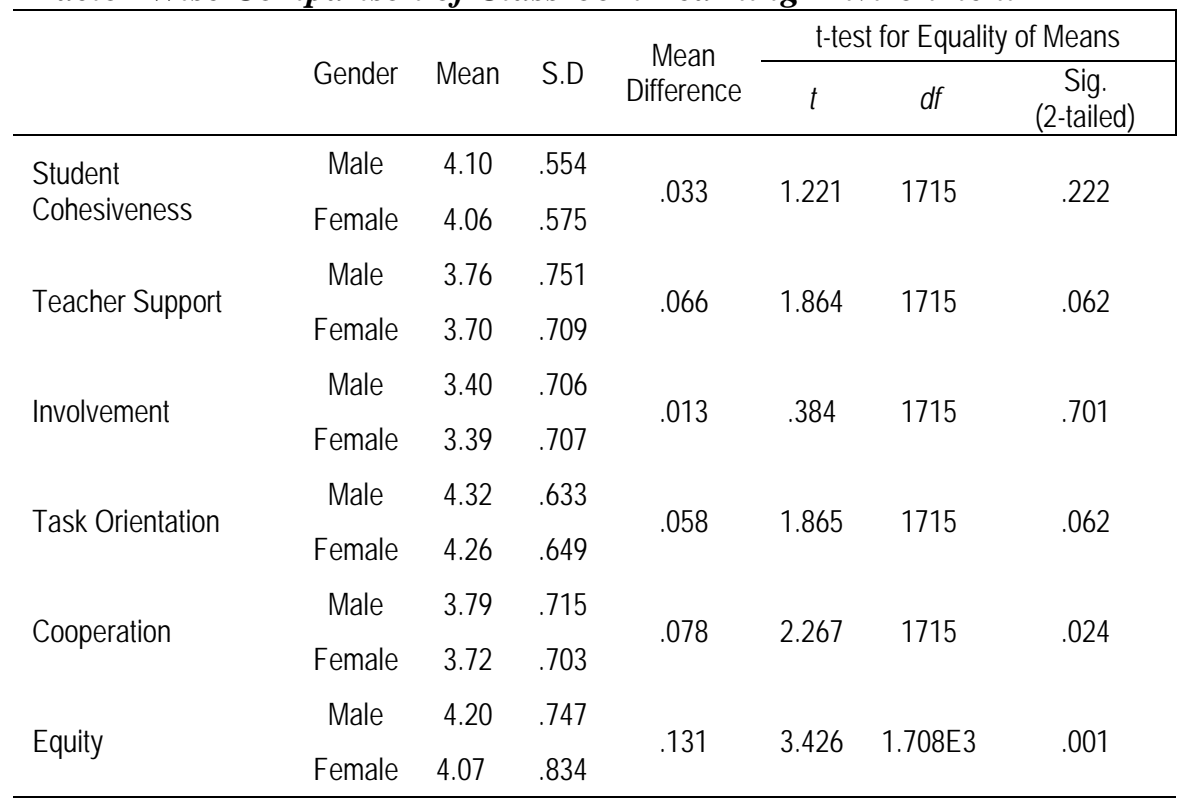

Analysis of data show that difference between male and female students' cohesiveness $(\mathrm{p}=.222>.05)$, teacher support $(\mathrm{p}=.062>.05)$, involvement $(\mathrm{p}=.701>.05)$, and task orientation $(\mathrm{p}=.062>.05)$, is not significant, whereas, difference in cooperation $(\mathrm{p}=.024<.05)$ and equity $(\mathrm{p}=.001<.05)$ among male and female students is significant. The mean score of equity for male students $(\bar{x}=4.20)$ is more than the mean score for females $(\bar{x}=4.07)$.

Table 3

Comparison of Male and Female Students' Attitude towards Mathematics

\begin{tabular}{|c|c|c|c|c|c|c|c|}
\hline & \multirow{2}{*}{ Gender } & \multirow{2}{*}{ Mean } & \multirow{2}{*}{ S.D } & \multirow{2}{*}{$\begin{array}{c}\text { Mean } \\
\text { Difference }\end{array}$} & \multicolumn{3}{|c|}{ t-test for Equality of Means } \\
\hline & & & & & $t$ & $d f$ & Sig. (2-tailed) \\
\hline 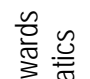 & Male & 3.28 & .485 & & & & \\
\hline 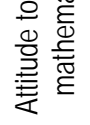 & Female & 3.19 & .467 & .09172 & 3.993 & 1715 & .000 \\
\hline
\end{tabular}


Analysis of data indicates that there exist significant difference $(p=.000<.05)$ between male and female students 'attitude towards mathematics. Therefore, the null hypothesis "There is no significant difference between male and female students' attitude towards mathematics is rejected. The mean score for attitude towards mathematics of male students $(\bar{x}=3.28)$ is more than the mean score for females ( $\bar{x}=3.19)$.

Table 4

Factor Wise Comparison of Attitude towards Mathematics of Male and Female Students

\begin{tabular}{lcccccccc}
\hline & & & & & \multicolumn{2}{c}{ t-test for Equality of Means } \\
\cline { 7 - 9 } & Gender & Mean & S.D & $\begin{array}{c}\text { Mean } \\
\text { Difference }\end{array}$ & & & df & $\begin{array}{c}\text { Sig. } \\
\text { (2-tailed) }\end{array}$ \\
\hline Attitude towards & Male & 3.45 & .610 & & & & \\
Mathematics Inquiry & Female & 3.38 & .612 & .070 & 2.374 & 1715 & .018 \\
Adoption of & Male & 3.23 & .599 & & & & \\
Mathematics Attitude & Female & 3.12 & .598 & .113 & 3.910 & 1715 & .000 \\
Enjoyment of & Male & 3.15 & .576 & & & & \\
Mathematics Lessons & Female & 3.06 & .546 & .092 & 3.404 & 1715 & .001 \\
\hline
\end{tabular}

Table 4 shows that the difference between male and female students' attitude towards Mathematics inquiry $(\mathrm{p}=.018<.05)$, adoption of Mathematics attitude $(\mathrm{p}=.000<.05)$, and enjoyment of Mathematics lessons is significant $(\mathrm{p}=.001<.05)$. Mean score for attitude towards Mathematics inquiry of male students $(\bar{x}=3.45)$ is more than that of females $(\bar{x}=3.38)$. Similarly, mean score for adoption of Mathematics attitude of male students $(\bar{x}=3.23)$ is again more than the mean score of females $(\bar{x}=3.12)$. The same is the case for mean score for enjoyment of Mathematics lessons $(\overline{\mathrm{x}}=3.15>\overline{\mathrm{x}}=3.06)$.

Table 5

Gender Wise Relationship of Classroom Learning Environment with Students' Attitude towards Mathematics

\begin{tabular}{llcc}
\hline $\begin{array}{l}\text { Classroom Learning } \\
\text { Environment }\end{array}$ & \multirow{2}{*}{} & \multicolumn{2}{c}{ Students' Attitude towards mathematics } \\
\cline { 3 - 4 } Male & & Pearson Correlation r & Sig. (2-tailed) \\
Female & 839 & $.113^{* *}$ & .001 \\
& 878 & $.129^{* *}$ & .000 \\
\hline
\end{tabular}


Table 5 reveals the gender wise relationship between classroom learning environment and students' attitude towards Mathematics. Analysis of data reflects that females show significant positive $(r=.129, p=.000)$ relationship between classroom learning environment and attitude towards Mathematics than males $(\mathrm{r}=.113, \mathrm{p}=.001)$. Null hypothesis "There is no significant relationship between classroom learning environment and students' attitude towards Mathematics.” is rejected $(\mathrm{p}=.000<0.05)$.

Table 6

Relationship of Classroom Learning Environment Factors with Sub Scales of Students' Attitude towards Mathematics (Male)

\begin{tabular}{|c|c|c|c|c|c|c|}
\hline \multirow{2}{*}{$\begin{array}{l}\text { Classroom Learning } \\
\text { Environment Factors }\end{array}$} & \multicolumn{2}{|c|}{$\begin{array}{l}\text { Attitude towards } \\
\text { Mathematics Inquiry }\end{array}$} & \multicolumn{2}{|c|}{$\begin{array}{c}\text { Adoption of } \\
\text { Mathematics Attitude }\end{array}$} & \multicolumn{2}{|c|}{$\begin{array}{c}\text { Enjoyment of } \\
\text { Mathematics } \\
\text { Lessons } \\
\end{array}$} \\
\hline & $r$ & $\begin{array}{c}\text { Sig. } \\
\text { (2-tailed) }\end{array}$ & $r$ & $\begin{array}{c}\text { Sig. } \\
\text { (2-tailed) }\end{array}$ & $r$ & $\begin{array}{c}\text { Sig. } \\
\text { (2-tailed) }\end{array}$ \\
\hline Student Cohesiveness & $.085^{\star \star}$ & .014 & $.098 * \star$ & .005 & .042 & .219 \\
\hline Teacher Support & $.107^{\star *}$ & .002 & .023 & .499 & $.070^{*}$ & .042 \\
\hline Involvement & $.126^{\star \star}$ & .000 & $.126^{\star \star}$ & .000 & $.078^{*}$ & .024 \\
\hline Task Orientation & .040 & .253 & -.021 & .546 & .007 & .850 \\
\hline Cooperation & $.116^{\star \star}$ & .001 & $.115^{\star \star}$ & .001 & $.103^{\star \star}$ & .003 \\
\hline Equity & .025 & .466 & -.022 & .522 & .016 & .641 \\
\hline
\end{tabular}

The table 6 shows that student cohesiveness of male students is significantly correlated with attitude towards Mathematics inquiry and adoption of Mathematics attitude. Moreover, teacher support is significantly correlated with attitude towards Mathematics inquiry and enjoyment of mathematics lessons for male students. Furthermore, involvement and cooperation are significantly correlated with all the sub factors of attitude for male students. 
Table 7

Relationship of Classroom Learning Environment Factors with Sub Scales of Students' Attitude towards Mathematics (Female)

\begin{tabular}{lcccccc}
\hline $\begin{array}{l}\text { Classroom Learning } \\
\text { Environment Factors }\end{array}$ & \multicolumn{2}{c}{$\begin{array}{c}\text { Attitude towards } \\
\text { mathematics Inquiry }\end{array}$} & \multicolumn{2}{c}{$\begin{array}{c}\text { Adoption of } \\
\text { mathematics Attitude }\end{array}$} & \multicolumn{2}{c}{$\begin{array}{c}\text { Enjoyment of } \\
\text { mathematics } \\
\text { Lessons }\end{array}$} \\
\cline { 2 - 7 } Student Cohesiveness & \multicolumn{1}{c}{$\begin{array}{c}\text { Sig. } \\
\text { (2-tailed) }\end{array}$} & $\mathrm{r}$ & $\begin{array}{c}\text { Sig. } \\
\text { (2-tailed) }\end{array}$ & $\mathrm{r}$ & $\begin{array}{c}\text { Sig. } \\
\text { (2-tailed) }\end{array}$ \\
\cline { 2 - 7 } Teacher Support & $.131^{* *}$ & .010 & .039 & .251 & .025 & .467 \\
Involvement & .021 & .532 & $.164^{* *}$ & .000 & $.117^{\star *}$ & .001 \\
Task Orientation & .058 & .088 & -.010 & .764 & -.017 & .624 \\
Cooperation & $.119^{* *}$ & .000 & $.143^{\star *}$ & .000 & $.074^{*}$ & .029 \\
Equity & $.079^{*}$ & .020 & .037 & .278 & .002 & .952 \\
\hline
\end{tabular}

The table 7 shows that student cohesiveness and equity of female students are significantly correlated with attitude towards Mathematics inquiry. Moreover, teacher support and cooperation are significantly correlated with all the sub factors of attitude for female students. Furthermore, involvement is significantly correlated with adoption of Mathematics attitude and enjoyment of Mathematics lessons for female students.

Table 8

Relationship between Classroom Learning Environment and Students' Attitude towards Mathematics

\begin{tabular}{lcc}
\hline & \multicolumn{2}{c}{ Classroom Learning Environment } \\
\cline { 2 - 3 } & Pearson Correlation r & Sig. (2-tailed) \\
\cline { 2 - 3 } $\begin{array}{l}\text { Students' Attitude towards } \\
\text { mathematics }\end{array}$ & $.119^{* *}$ & .000 \\
\hline
\end{tabular}

The above table reflects that there exist significant positive $(r=.119$, $\mathrm{p}=.000$ ) correlation between classroom learning environment and students' attitude towards Mathematics. Null hypothesis "there is no significant relationship between Mathematics classroom learning environment and students' attitude towards Mathematics” is rejected $(\mathrm{p}=.000<0.05)$. 
Table 9

Impact of Classroom Learning Environment on Students' Attitude towards Mathematics

\begin{tabular}{|c|c|c|c|c|c|c|c|c|c|c|c|c|}
\hline \multirow{2}{*}{ Factors } & \multicolumn{4}{|c|}{$\begin{array}{l}\text { Attitude towards } \\
\text { Mathematics Inquiry }\end{array}$} & \multicolumn{4}{|c|}{$\begin{array}{c}\text { Adoption of Mathematics } \\
\text { Attitude }\end{array}$} & \multicolumn{4}{|c|}{$\begin{array}{c}\text { Enjoyment of } \\
\text { Mathematics Lessons }\end{array}$} \\
\hline & $r$ & Sig. & B & Sig. & $r$ & Sig. & B & Sig. & $r$ & Sig. & $\beta$ & Sig. \\
\hline $\begin{array}{l}\text { Student } \\
\text { Cohesiveness }\end{array}$ & .088 & .000 & .030 & .271 & .070 & .002 & -.002 & .949 & .036 & .070 & -.023 & .412 \\
\hline $\begin{array}{l}\text { Teacher } \\
\text { Support }\end{array}$ & .121 & .000 & .101 & .000 & .059 & .007 & .025 & .383 & .074 & .001 & .063 & .027 \\
\hline Involvement & .073 & .001 & .000 & .971 & .145 & .000 & .110 & .000 & .098 & .000 & .067 & .016 \\
\hline $\begin{array}{l}\text { Task } \\
\text { Orientation }\end{array}$ & .051 & .017 & .020 & .490 & -.011 & .324 & -.075 & .010 & -.001 & .477 & -.050 & .092 \\
\hline Cooperation & .120 & .000 & .095 & .002 & .133 & .000 & .131 & .000 & .092 & .000 & .092 & .002 \\
\hline Equity & .058 & .008 & -.023 & .441 & .017. & 239 & -.039 & 191 & . 015. & 262 & -.038 & .206 \\
\hline $\mathrm{R}$ & \multicolumn{4}{|c|}{.154} & \multicolumn{4}{|c|}{.187} & \multicolumn{4}{|c|}{.135} \\
\hline $\mathrm{R}^{2}$ & \multicolumn{4}{|c|}{.024} & \multicolumn{4}{|c|}{.035} & \multicolumn{4}{|c|}{.018} \\
\hline
\end{tabular}

The values of standard beta weights showed that teacher support has significant effect on attitude towards Mathematics inquiry $(\beta=.101$, $\mathrm{p}<.05)$ and enjoyment of Mathematics lessons $(\beta=.063, \mathrm{p}<.05)$. Similarly, the values of standard beta weights showed that involvement has significant effect on adoption of Mathematics attitude $(\beta=.110$, $\mathrm{p}<.05)$ and enjoyment of Mathematics lessons $(\beta=.067, \mathrm{p}<.05)$.

Likewise, the values of standard beta weights showed that task orientation has significant effect on adoption of Mathematics attitude ( $\beta=-.075, \mathrm{p}<.05$ ). Similarly, the values of standard beta weights showed that cooperation has significant effect on attitude towards Mathematics inquiry $(\beta=.095, p<.05)$, adoption of Mathematics attitude $(\beta=.131$, $\mathrm{p}<.05)$ and enjoyment of Mathematics lessons $(\beta=.092, \mathrm{p}<.05)$.

Moreover, multiple correlation between classroom learning environment and attitude towards mathematics inquiry $\left(r^{2}=.024\right)$ reflects that classroom learning environment slightly influence attitude towards mathematics inquiry. Similarly, multiple correlation between classroom learning environment and adoption of Mathematics attitude $\left(r^{2}=.035\right)$ again shows slight effect. Finally, multiple correlation between classroom learning environment and enjoyment of Mathematics lessons $\left(r^{2}=.018\right)$ again indicates minor effect of classroom learning environment on enjoyment of 
Mathematics lessons. Hence, it may be stated that classroom learning environment has a feeble effect on attitude towards Mathematics.

\section{Conclusions}

Both the male and female students show significant difference in their attitudes about learning environment of classroom. The male students perceived more supportive Mathematics classroom learning environment than females. As far as the factors of classroom learning environment are concerned there exists a significant difference in equity and cooperation among male and female students. The male students perceived more equity and cooperation in Mathematics classroom than females.

It is observed that the difference in male and female students' Mathematics related attitude is also significant. The mean score for attitude towards Mathematics of male students is more than the mean score for females. As far as the sub factors of attitude towards Mathematics are concerned, there existed significant difference in male and female students' attitude towards adoption of Mathematics attitude, Mathematics inquiry, and enjoyment of Mathematics lessons.

High level of Mathematics classroom learning environment helps the students to develop the positive attitude towards Mathematics. Moreover, there exists significant relationship between male and female students' perceptions about the relationship of classroom learning environment with their attitude towards Mathematics.

For the male students, cohesiveness may improve attitude towards Mathematics inquiry and adoption of Mathematics attitude. Moreover, teacher support helps to develop positive attitude towards Mathematics inquiry and enjoyment of Mathematics lessons. Furthermore, students' involvement in their class work and cooperation with one another to complete the learning tasks boosts their attitude towards adoption of Mathematics attitude, Mathematics inquiry and enjoyment of Mathematics lessons.

Similarly for female student, cohesiveness and equity may enhance attitude towards Mathematics inquiry. Moreover, teacher support and cooperation helps to develop positive attitude towards Mathematics inquiry, adoption of mathematics attitude and enjoyment of Mathematics 
lessons. Furthermore, students' involvement in their class work boosts up their adoption of Mathematics attitude and enjoyment of Mathematics lessons. On the whole, it may be concluded that classroom learning environment has a feeble effect on attitude towards mathematics.

\section{Discussion}

The present study aimed at exploring the relationship between classroom learning environment and students' attitude towards Mathematics. It reveals that mathematics classroom learning environment helps the students to develop the positive attitude towards Mathematics. Moreover, there exist gender based difference to some extent regarding the relationship between classroom learning environment and attitude towards Mathematics in Pakistan. Furthermore, student cohesiveness, teachers' support, involvement and cooperation of the students are significantly correlated with attitudinal outcomes. The reason is that most of the male and female students of Pakistani colleges are facing similar conditions such as curriculum, pedagogical practices and mode of assessment and evaluation within the same premises of the colleges. The findings of the study supports Fraser's (1994) view that classroom learning environment strongly influences students' affective outcomes. In the same way, the results of the study are consistent with the previous studies (Fraser, 1998; Mobeen-ul-Islam, 2012). In order to enhance the students' attitude towards Mathematics, practical strategies should be implemented for the improvement of classroom learning environment.

Similarly, high level of student cohesiveness, task orientation, teacher support, involvement and cooperation in classrooms both for male and female students may help in shaping positive attitude towards Mathematics inquiry, adoption of Mathematics attitude and enjoyment of mathematics lessons. Moreover, these factors predict the students' attitude towards Mathematics in higher secondary level Mathematics students. The study at hand supports the results of the study conducted by Mobeen-ul-Islam (2012) in Pakistan. Similarly, the results of the study are in accordance with the previous studies carried out in other regions like Turkey, India, Korea and Australia (Kim, Fisher, \&Fraser, 2000; Okan, 2008).

The perception of the female students about learning environment is more positive than the boys but the present study does not support this result by stating that the perception of the male students about 
Mathematics classroom learning environment is more supportive than that of females (Fraser \&Mcrobbie, 1995; Rawnsley\&Fisher, 1997). Additionally, there exists significant difference in equity and cooperation among male and female students. In Pakistani perspective, the male students perceived more equity and cooperation in Mathematics classroom than that of females. Kim, Fisher and Fraser (2000), indicate the same results in case of equity while on the other hand, in terms of cooperation the results contradict with the results reported by Rawnsleyand Fisher (1997).

There exists significant difference between male and female students' attitude towards Mathematics. Attitude towards Mathematics of male students is better than that of females. The results of the study are consistent with the previous studies that boys show more positive attitude towards Mathematics than girls (Mahanta \& Islam, 2012). In addition, several studies indicate that boys show more positive attitude towards Mathematics than girls (Hyde, Fennema, Ryan, Frost, \& Hopp, 1990; Odell \&Schumacher, 1998; Meelissen \& Luyten, 2008). However, different studies indicate no significant difference among male and female students' attitude towards Mathematics (Nicolaidou \& Philippou, 2003; Köğce, Yildiz, Aydin, \&Altindağ, 2009; Mohd, Mahmood, \&Ismail, 2011). Similarly, the results of the study reported by Anwer and Iqbal (2012) support the findings of the present study that attitude towards Mathematics inquiry, adoption of Mathematics attitude, and enjoyment of Mathematics lessons of males is better than that of females.

\section{Recommendations}

The following recommendations are offered based on the results of the study:

1. Mathematics classroom learning environment may be made conducive for females by improving the student cohesiveness, involvement, cooperation and teacher support.

2. Physical learning environment as well as psycho-social learning environment is the neglected parts of Pakistani National Education policy. Therefore, the policy-makers may focus these two aspects for the improvement of the students' achievement and attitude towards Mathematics. 
3. For developing a conducive and psycho-social learning environment, the teachers may be provided with refresher courses and training workshops arranged by the department of Education.

4. Such studies may also be carried out in other parts of Pakistan to highlight the issues brought to light via the current research. Moreover, this research may also be replicated for the Mathematics teachers and students at others level i.e. for higher education level and the elementary level.

5. The similar study may be carried in different disciplines like Chemistry, Biology, Physics, and English etc.

6. Cross-cultural studies may be conducted to explore the relationship among these variables.

\section{REFERENCES}

Akey, (2006).School context, students' attitudes and behavior and academic achievement: an exploratory analysis, Tech. Rep., MDRC.

Ames, C. A.(1992). Classrooms: Goals, structures, and student motivation. Journal of Educational Psychology, 84, 261-271.

Anderson, G., \& Walberg, H. (1974).Evaluating educational performance. In H. J. Walberg (Ed.), Evaluating educational performance: A sourcebook of methods, instruments, and examples (pp. 81-98). Berkley, CA: McCutchan.

Anwer \& Iqbal, (2012). Students' attitude towards science: A case of Pakistan. Pakistan Journal of Social and Clinical Psychology 2012, Vol. 9, No. 2, 3-9.

Baker, D., \& Jacobs, K. (1999).Winners and losers in single-sex science and mathematics classrooms. Rep. Boston

Bono, D. (1991). The impact of cooperative learning on suzy and janie's attitude about math. Research report in Virginia, 137-167.

Brock, L. L., Nishida, T. K., Chiong, C., Grimm, K. J. \& Rimm, Kaufman, S. E. (2008).Children's perceptions of the classroom environment and social and academic performance: A longitudinal analysis of the contribution of the Responsive Classroom approach, Journal of School Psychology, 46, 129-149. 
Brophy, J. (1999). Teaching. Brussels: International Academy of Education.

Church, M. A., Elliot, A. J. \& Gable, S. L. (2001).Perceptions of classroom environment, achievement goals, and achievement outcomes, Journal of Educational Psychology, 93, 43-54.

Condition of Education.(1998). Climate and diversity of educational institutions.

Dorman, J.P. (2002). Classroom environment research: Progress and possibilities. Retrieved from http://www.iier.org.au/qjer/qjer18/ dorman.html

Fisher, D. L., \& Khine, M. S. (2006). Contemporary approaches to research on learning environments: Worldviews. Singapore: World Scientific.

Fisher, D., \& Rickards, T. (1998).Associations between teacher-student interpersonal behavior and student attitude towards mathematics. mathematics Education Research Journal, 10(1), 3-15.

Fraser, B. J. (1994). Research on classroom and school climate. In D. L. Gabel (Ed.), Handbook of research on science teaching and learning (pp.493541). New York: Macmillan.

Fraser, B. J. (1998). Science learning environments: Assessment, effects and determinants. In B. J. Fraser \& K. G. Tob (Eds.), The international handbook of science education (pp. 527-564). Dordrecht: Kluwer Academic Publishers.

Fraser, B. J. (2002a). Learning environments research: yesterday, today and tomorrow. In s. C. Goh\& M. S. Khine (Eds.), Studies in educational learning environments: an interpersonal perspective (pp. 1-27). Singapore: World Scientific Publishers.

Fraser, B. J. (2007). Classroom learning environments In S. K. Abell \& N. G. Lederman (Eds.), Handbook of research on science education (pp.103-124). Mahwah, NJ Lawrence Erlbaum.

Fraser, B. J., \& Walberg, H. J. (1991). Educational environments: Evaluation, antecedents and consequences. Oxford, GB: Pergamon.

Fraser, B. J., \& McRobbie, C. J. (1995). Science laboratory classroom environments at schools and universities: A cross-national study. Educational Research and Evaluation, 1(4), 289-317.doi:10.1080/ 1380361950010401 
Fraser, B.J. (1998). Science Learning Environments: Assessments, Effects and Determinants. In B.J. Fraser \& K. Tobin (Eds.) International Handbook of Science Education, 527-564. Dordrecht, The Netherlands: Kluwer.

Galbraith, M. W. (1989). Essential Skills for the Facilitator of Adult Learning. Lifelong Learning: An Omnibus of Practice and Research, 12(6), 10-13.

Galbraith, M. W. (1990). Attributes and skills of an adult educator. In M. W. Galbraith (Ed.), Adult Learning Methods, Fla: Robert E. Krieger.

Gill, (1994).Shedding some new light on old truths: Student attitudes to school in terms of year level and Gender, Annual meeting of the American Educational Research association, New Orleans, LA. pp. 4-9.

Goh, S. C., \& Fraser, B. J. (1998).Teacher interpersonal behaviour, classroom environment and student outcomes in primary mathematics in Singapore. Learning Environments Research, 1, 199-229.

Haladyna, T., Shaughnessy, J., Shaughnessy, M. (1983). A causal analysis of attitude toward mathematics. Journal for Research in mathematics Education, 14 (1), 19-29.

Halimah Awang \& Noor Azina Ismail.(2006). Gender differences in mathematics learning in Malaysia. Mlaysia: University of Malaya.

Henderson, D., Fisher, D., \& Fraser, B. (2000).Interpersonal behaviour, Laboratory learning environments, and student outcomes in senior biology classes. Journal of Research in Science Teaching, 37(1), 26-43. DOI: 10.1002/ (SICI) 1098-2736 (200001).

Herbert, K. (1978). The new book of popular science daribury, Connecticut: Grolier Inc.

Huang, S. L. (2003). Antecedents to psychosocial environments in middle school classrooms in Taiwan. Learning Environments Research 6, 119-135. Integrated Science. Unpublished Ph. D Thesis, University of Ibadan.

Huang, S. L., \& Waxman, H. C. (1995a).Differences between Asian- and Anglo-American students' motivation and learning environments. In D. Fisher (Ed.), The study of learning environments, Volume 8 (pp. 129-144). Perth, Australia: Curtin University of Technology. 
Hyde, J.S., Fennema, E., Ryan, M., Frost, L.A., \& Hopp, C. (1990). Gender comparisons of mathematics attitudes and affect: A meta-analysis. Psychology of Women Quarterly, 14(3), 299-324.

Khoo, H., \& Fraser, B. J. (1998).Using classroom environment dimensions in the evaluation of adult computer courses. Paper presented at the annual meeting of the National Association for Research in Science Teaching, San Diego, CA.

Kim, H. B., Fisher, D. L., \& Fraser, B. J. (2000).Classroom environment and teacher interpersonal behaviour in secondary science classes in Korea.Evaluation and Research in Education, 14, 3-22.

Köğce, D., Yıldız, C., Aydın, M. \& Altındağ, R., (2009).Examining elementary school students' attitudes towards mathematics in terms of some variables, Procedia Social and Behavioral Sciences, 1(1), 291-295.

Koul, R.B., \& Fisher, D. (2004).A study of students' perceptions of science classroom learning environment and teacher-student interaction in Jammu: A cultural perspective. Perth: Curtin University of Technology, Western Australia.

Lawrenz, F. (1987). Sex effects for student perception of the classroom psychosocial environment. Journal of Research in Science Teaching 24, 689-97.

Maat and E. Zakaria, (2010).The learning environment, teacher's factor and student's attitudes towards mathematics amongst engineering technology students. International Journal of Academic Research, vol. 2, no. 2, pp. 16-20.

Mahanta, S. \& Islam, M. (2012).Attitude of secondary students towards mathematics and its relationship to achievement in mathematics. International Journal Computer Technology \& Applications, 3(2), 713-715.

McLeod, D. B. (1992).Research on affect in mathematics education: A reconceptualization. In handbook of research on mathematics teaching and learning, edited by D. A. Grouws. New York: Macmillan.

Meelissen, M. \& Luyten, H. (2008). The Dutch gender gap in mathematics: Small for achievement, substantial for beliefs and attitudes. Studies in Educational Evaluation, 34, 82-93. 
Midgely, C., Feldlaufer, H., \&Eccles, J. (1989). Change in teacher efficacy and student self- and task-related beliefs in mathematics during the transition to junior high school. Journal of Educational Psychology, 81, 247-258.

Mobeenul Islam, (2012). Impact of students' perceptions about teacher interaction and classroom learning environment on attitude towards mathematics and achievement. Unpublished Doctoral Thesis. Lahore: IER, University of the Punjab.

Mohd, N., Mahmood, T. F. P. T., \& Ismail, M. N. (2011). Factors that influence students in mathematics achievement. International Journal of Academic Research, 3(3), 49-54.

Moos, R. (1974). The social climate scales: An overview. Palo Alto, CA: Consulting Psychologists Press.

Moos, R. H. (1979).Evaluating environments: Measures, procedures, findings and policy implications. San Francisco, CA: Jossey-Bass.

Mullis, I. V. S., M. O. Martin, E. J. Gonzalez, K. M. Conner, S. J. Chrostowski, K. D. Gregory, R. A. Garden and T. A. Smith (2001), mathematics benchmarking report.

Nicolaidou, M. \& Philippou, G. (2003).Attitudes towards mathematics, selfefficacy and achievement in problem solving. European Research in mathematics III.

Novotney, A. (2011). Coed verses single-sex education. American Psychological Association. 42(2).

Odell, P. M. \& Schumacher, P. (1998). Attitudes towards mathematics and predictors of college mathematics grades: gender difference in a 4-year business college. Journal of Education for Business, 74(1), 34-38.

Okan, Z. (2008).Computing laboratory classes as language learning environments. Learning Environments Research, 11, 31-48.Doi: 10.1007/s10984-007-9035-y

Pajares, F., \& Graham, L. (1999). Self-Efficacy, motivation constructs and mathematics performance of entering middle school students. Contemporary Educational Psychology, 24, 124-139.

Ramsden, J. (1998). Mission impossible? Can anything be done about attitudes to science? International Journal of Science Education, 20, 125-137. 
Rawnsley, D. \& Fisher, D. (1998).Learning environments in mathematics classrooms and their associations with students' attitudes and learning. Paper presented at the Australian Association for Research in Education Conference, Adelaide, Australia. Retrieved from http://www.aare.edu.au/ 98pap/fis98269.htm

Rawnsley, D. \& Fisher, D. L. (1997). Using personal and class forms of a learning environment questionnaire in mathematics classroom. In D. L. Fisher \& T. Rickard (Eds.), Science, mathematics and Technology Education and National Development: Proceedings of the Vietnam Conference (pp. 52-63). Hanoi: Vietnam.

Reynolds, A. J., \& Walberg, H.J. (1992).A structural model of high school mathematics outcomes. Journal of Educational Research, 85(3), 150-158.

Salta, K. \& Tzougraki, C. (2004). Attitudes toward Chemistry among 11th grade students in High schools in Greece. Science Education, 88, 535-547.

Simpson, R. D., \& Oliver J. S. (1990).A summary of major influences on attitude and achievement in science among adolescent students. Science Education, 74, 1-18.

Swetman, D., (1995). Rural elementary students' attitudes toward mathematics. Rural Educator, 16 (3) Springer pp. 20-22.

Vacha, E. (1977). Improving the classroom social climate. Orcutt, CA: Holt, Rinehart \& Winston.

Wentzel, K. (1998). Social relationships and motivation in middle school: The role of parents, teachers, and peers, Journal of Educational Psychology, 90, 202-209.

Wilson, B. G. (1996). Introduction: What is a constructivist learning environment? In B. G. Wilson (Ed.).Constructivist Learning Environment (pp. 38). Englewood Cliffs, N.J: Educational Technology Publications.

Received on: June $30^{\text {th }} 2015$

Revised on: October $18^{\text {th }} 2015$ Accepted on: November $11^{\text {th }} 2015$ 